to Plymouth and the south-west. In this work his scientific experience of the fishing industry and its methods, and his knowledge of the habits of fishes, made him a valuable adviser. He retired from service in 1937, but was temporarily re-employed from the outbreak of war until the beginning of 1944 .

Todd had great charm, and will be especially remembered as a kind friend by members of a younger generation on the staff of the Plymouth Laboratory whom he and his wife made so welcome at their home in Elburton, outside Plymouth. Here he was always most anxious to discuss problems of natural history, and to the end he took a lively interest in the work of the Laboratory at which he started his scientific career. He passed away without suffering after a long illness patiently borne, and the sympathy of his many friends will be extended to Mirs. Todd in her bereavement.

F. S. RUSSELL

WE regret to announce the following deaths :

Dr. F. S. Locke, formerly reader in physiology at King's College, University of London, on May 5, aged eighty-three.

Count Maurice Maeterlinck, philosopher and naturalist, on May 6, aged eighty-six.

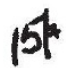

University of Nottingham: Installation of the Chancellor

FuLL university sty tras conferred on University College, Notting d m, by the King in Council on July 9, 1948 (see Hature, August 14, p. 240) ; Lord Trent was instrited as chapellor of the new University on

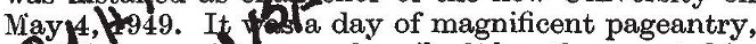
of i the occar on was described by the great historlan, Dr. G. M. Trevelyan, as truly historic. The long procession included representatives of seventeen foreign universities and of eighteen British and Commonwealth universities and university colleges, members of the University Grants Committee, students and staff of the University of Nottingham, the Lord Mayor of Nottingham, and the mayors of neighbouring towns. The vice-chancellor (Mir. B. L. Hallward) opened the meeting and called upon the senior pro-chancellor (the Duke of Portland) and the registrar to lead in the Chancellor. As the Chancellor's procession entered the hall, preceded by the macebearer in colourful costume, it was greeted by a fanfare of trumpets. On reaching the platform, the Chancellor was installed by the Duke of Portland, who delivered an address of welcome; he was followed by representatives of other universities. Then Lord Trent received the University's first honorary degree, that of doctor of laws. In returning thanks, Lord Trent described a university "as a seat of learning at which the habit of exact thinking is inculcated and the quest for truth is pursued for its own sake. It is in this sense that our University must be judged as a training ground for future leaders, at every level, of science, and of the arts and professions. The most important factor in industry to-day is the human one. Technical ability is not enough without leadership and vision, and to my mind the best training for these qualities is a course in the humanities."

The remainder of the ceremony consisted in the conferment of honorary degrees on Lord Macmillan, Lord of Appeal, Dr. G. M. Trevelyan, Sir Walter Moberly, chairman of the University Grants Committee, and Mr. E. W. Hives, the eminent engineer who is managing director of Rolls-Royce. The public orator, Prof. W. J. Sprott, introduced the graduands, mixing well-deserved praise with occasional gentle thrusts of humorous raillery. Lord Macmillan, in reply, emphasized the relation of a modern university to commerce and industry. He also referred to the long and fruitful association of Nottingham University College with the University of London, of the Court of which he was for many years chairman. Dr.
Trevelyan pointed out that Oxford and Cambridge are nearly at saturation point in numbers. If university expansion on a large scale is to take place, it should take place chiefly in the newer universities. "It must be an inspiring thing to belong to the newest University, so splendidly situated and equipped, in these days when the tide is with you and the future of things academic is so full of value and promise." At a luncheon held at the University before the installation, Sir Walter Mioberly, toasting the University, said the auguries for its future were good. It had the support of the authorities and the people not only of the city but of the whole region; it had a home and setting which must be the envy of most universities in Britain and the beauty and dignity of which must be an inspiration to all who entered it; it had already given evidence that it could produce men who had made distinguished contributions to scholarship and who had a high, austere ideal of knowledge.

\section{University of Malaya}

THE University of Malaya, created by local legislation enacter in March and April, is the youngest university ine British Commonwealth. Its basis is the furon of the King Edward VII College of Medicin (1905) and Raffles College (1928), in accordand with the recommendations of the Commission on University Education which, under Sir Alexander Carr-Saunders, visited Malaya in 1947. For some years the University will use the buildings and grounds in Singapore of the two constituent colleges, but hopes soon to begin to erect completely new accommodation on an as yet undeveloped site on the mainland. His Miajesty's Govermment has promised $£ 1,000,000$ towards the building fund. The chancellor, Mr. Malcolm Macdonald, has launched an appeal for contributions to an endowment fund. The first vicechancellor is Dr. G. V. Allen, formerly principal of the College of Medicine. The Faculties of Arts (including social studies), Science and Medicine (including dentistry) will continue the teaching work of the two colleges and will shortly be developed to include departments of Chinese, Malay and Tamil studies. Among the research activities connected with the University are an Ionospheric Research Station, staffed and financed by the United Kingdom National Physical Laboratory, and a Tropical Research Unit, investigating the physiological and psychological effects of a tropical climate, staffed and financed by the Medical Department of the Royal Navy and the Medical Research Council. 